na Hemara, w wykonaniu artystów scen warszawskich, którzy przypomnieli przeboje minionych epok i jeszcze raz udowodnili, że piosenka też może być przedmiotem kolekcjonerstwa, a pamięć o niej zależy tylko od ludzi.

Temat seminarium i wyjątkowo atrakcyjna forma jego prezentacji spotkały się z uznaniem obecnych na sali, m.in. pracowników naukowych Instytutu Badań Literackich PAN i Instytutu Sztuki PAN.

Dorota Piętka-Hadata

(Archiwum Polskiej Akademii Nauk w Warszawie)

\title{
RADZYŃSKIE WARSZTATY ArChIWISTYCZNe 2007-2010
}

(Cztery odsłony Radzyńskich Warsztatów Archiwistycznych, zorganizowanych w ostatnich latach, to dorobek, sprawiający, że można już mówić o pewnej tradycji nie tylko dla kilku roczników studentów archiwistyki, lecz także dla samego miasta, w którym się odbywają. W Radzyniu Podlaskim, bo o nim mowa, gościli już studenci ze wszystkich stron „archiwistycznej Polski”. Koncepcję oraz formułę warsztatów ustalili w 2007 r. dwaj historycy: Artur Górak z UMCS oraz Dariusz Magier z Akademii Podlaskiej w Siedlcach. Warto ponadto nadmienić, że głównym koordynatorem warsztatów jest radzyński oddział AP w Lublinie, którego kierownikiem jest wspomniany D. Magier.

Każde z czterech spotkań archiwistów odbywało się według ustalonej formuły. Warsztaty zostały rozłożone na dwa dni. W pierwszym dniu studenci uczestniczyli w wykładach prowadzonych przez organizatorów oraz zaproszonych gości - głównie wykładowców uniwersyteckich. Drugi dzień poświęcono na zajęcia o charakterze typowo warsztatowym, a studenci mogli doskonalić swoje umiejętności jako archiwiści. Na temat tej formuły wypowiadali się sami organizatorzy. W 2008 r. A. Górak mówił: „do tej pory nie było w Polsce konferencji, na której by wykładowcy specjalnie organizowali dyskusje dla studentów. Owszem, były konferencje, gdzie studenci przygotowywali referaty dla studentów, gdzie naukowcy przygotowywali referaty dla naukowców i studentów, ale żeby specjalnie dla studentów - nie, i to jest pierwsze tego typu doświadczenie, które ma już drugą edycję i właśnie jest w Radzyniu. Radzyń może stać się Medyną archiwistyki, tak jak Mekką jest Toruń”" Każdo-

1 Toruń Mekka, a Radzyń Medyną, Grot, nr 14 z 9 V 2008, s. 12. 
razowo spotkanie studentów jest także okazją do integracji nie tylko samych żaków, lecz również uczestniczących w organizowanym corocznie spotkaniu integracyjnym referentów.

W pierwszych warsztatach (5-6 czerwca 2007 r.) wzięli udział słuchacze szkół wyższych oferujących kształcenie w zakresie specjalności archiwistycznej i zarządzania dokumentacją. Pojawili się więc żacy reprezentujący następujące uczelnie: Akademię Podlaską w Siedlcach, Państwową Wyższą Szkołę Zawodową w Chełmie, UMCS oraz Kolegium Licencjackie UMCS w Białej Podlaskiej. Wykłady otworzyło niezwykle ciekawe wystąpienie A. Góraka, który omówił „Zmiany w pracy kancelarii na przestrzeni XIX i XX w.” Podjęte kwestie dotyczyły funkcjonowania registratur w państwach poszczególnych zaborców. Kamil Piech poruszył nowe wówczas zagadnienie „Zastosowania norm ISO w pracy współczesnej kancelarii”. Ważną problematykę podjął także D. Magier, przedstawiając „Przemiany w teorii i praktyce archiwalnej”. Ostatni referat, zatytułowany „Prowadzenie akt osobowych w zakładach pracy", wygłosiła Beata Magier. Podczas drugiego dnia żacy uczestniczyli w ćwiczeniach praktycznych ${ }^{2}$.

W dniach 29-30 kwietnia 2008 r. Radzyń stał się po raz drugi miejscem spotkania studentów archiwistyki. Organizatorom udało się zgromadzić ponad stu adeptów archiwistyki z Akademii Podlaskiej w Siedlcach, Państwowej Wyższej Szkoły Zawodowej w Chełmie, UMCS w Lublinie oraz Kolegiów Licencjackich UMCS w Białej Podlaskiej i Radomiu. Tematami przewodnimi ówczesnej konferencji były współczesna kancelaria i archiwum zakładowe. Tym razem wygłoszono aż pięć wykładów. Jako pierwszy wystąpił D. Magier, który w interesujący sposób wykazywał „Co o nadzorze archiwalnym wiedzieć należy”. Odczyt Małgorzaty Wnuk z Akademii Świętokrzyskiej w Kielcach, Filia w Piotrkowie Trybunalskim, zatytułowany „W kręgu records management - od dokumentacji papierowej do elektronicznej”, przybliżył studentom problematykę związaną z archiwaliami o charakterze cyfrowym. A. Górak tym razem opowiedział o „Pragmatyce wykazu akt”, natomiast dzięki Robertowi Degenowi z UMK żacy mogli zostać wtajemniczeni w temat „Budowa i funkcje instrukcji kancelaryjnej instytucji”. Blok wykładów zamknęło wystąpienie Joanny Kowalik z radzyńskiego oddziału AP w Lublinie, która zaprezentowała komputerową archiwalną bazę danych NADZÓR. Następnego dnia studenci zapoznali się z historią Radzynia Podlaskiego, zwiedzili jego zabytki, przede wszystkim pochodzący z XVII w. zespół pałacowo-parkowy.

2 Powrót studentów do Radzynia (choć na krótko), Wspólnota Radzyńska, nr 24 z 13 VI 2007, s. V. 
Druga edycja warsztatów utwierdziła organizatorów w przekonaniu, że istnieje duża potrzeba zwoływania tego rodzaju spotkań o charakterze branżowym. Najlepiej może o tym zaświadczyć głos jednego z uczestników warsztatów, studenta Michała Szabrańskiego, który zauważył, że „te warsztaty okazały się bardzo przydatne, ponieważ było dużo zajęć praktycznych. To, co na wykładach mówili doktorzy i magistrowie, tutaj było pokazane w praktyce. Ja na przykład bardzo skorzystałem na tym, co mówił Degen odnośnie do instrukcji kancelaryjnych. Także zarówno ja, jak i moi koledzy z Lublina cieszymy się z możliwości takich spotkań i uczestnictwa w nich"3.

III Radzyńskie Warsztaty Archiwistyczne odbywały się w dniach 14-15 maja 2009 r. Do Radzynia Podlaskiego zawitały wówczas grupy studenckie z Kolegium Licencjackiego UMCS w Białej Podlaskiej, Państwowej Wyższej Szkoły Zawodowej w Chełmie, UMCS, Akademii Podlaskiej w Siedlcach oraz UMK. Tym razem motywem przewodnim spotkania stały się zagadnienia związane $\mathrm{z}$ urzędem gminy oraz jego kancelarią i wytwarzaną przezeń dokumentacją. Blok wykładowy otworzył Marek Konstankiewicz z UMCS, który omówił temat „Ustrój i organizacja urzędu gminy i jednostek organizacyjnych samorządu gminnego”. „Instrukcja kancelaryjna i wykaz akt dla samorządu gminnego: wady i optymalizacja” były przedmiotem rozważań A. Góraka. Studenci wysłuchali następnie wystąpienia J. Kowalik. Nazajutrz, w ramach zajęć praktycznych, zadaniem studentów było samodzielne opracowanie instrukcji kancelaryjnej wybranego urzędu - jednostki organizacyjnej samorządu gminnego.

Zgromadziwszy blisko 50 studentów, IV Radzyńskie Warsztaty Archiwistyczne odbywały się, w odróżnieniu od trzech poprzednich konferencji, w Bibliotece Pedagogicznej w Radzyniu Podlaskim. W dniach 13-14 kwietnia 2010 r. miasto gościło żaków z Lublina, Siedlec, Torunia, Białej Podlaskiej, Chełma oraz - po raz pierwszy - Warszawy. Tematem przewodnim ogłoszono „Archiwum cyfrowe”. Pierwszy referat, pt. „Archiwistyka wobec wyzwań świata cyfrowego”, wygłosił D. Magier. Prelegent wskazał na ważne aspekty, mające związek $\mathrm{z}$ archiwizacją informacji w formie cyfrowej, oparte na doświadczeniach Australii, Kanady i Stanów Zjednoczonych. Artur Rogalski z AP w Siedlcach, w wystąpieniu „Popkulturowe wyzwania archiwistyki”, zilustrował postrzeganie archiwów i archiwistów przez „świat zewnętrzny” oraz sposoby popularyzacji dziedzictwa archiwalnego. Z kolei A. Górak zaprezentował „Wymagania podmiotów gospodarczych wobec elektronicz-

3 Studenci wystuchali wyktadów fachowców od archiwów, Wspólnota Radzyńska, nr 19 z 7 V 2008, s. 10. 
nych narzędzi zarządzania dokumentacją”. Dalszą część warsztatów zdominowały prezentacje. Grzegorz Gałęzowski, informatyk z AP w Lublinie, mówił o „Skutecznym przechowywaniu zasobów cyfrowych”. Rafał Magryś, pracownik NAC, omówił budowę archiwum elektronicznego, ilustrując wystąpienie przykładem swojej macierzystej placówki. Poprowadził on także zajęcia warsztatowe 14 kwietnia. Zapoznał wówczas studentów z Systemem Informacji Archiwalnej ZoSIA ${ }^{4}$.

Podczas II Radzyńskich Warsztatów Archiwalnych D. Magier stwierdził: „Znaczne rozszerzenie zakresu warsztatów w porównaniu z ubiegłorocznym zjazdem bardzo raduje organizatorów. Radzyńskie Warsztaty Archiwistyczne wyrastają na drugą co do skali przedsięwzięcia imprezę studenckich kół naukowych archiwistów w Polsce po dorocznym Ogólnopolskim Zjeździe Studentów Archiwistyki, stają się sztandarowym przedsięwzięciem radzyńskiego oddziału archiwum państwowego" ${ }^{5}$. Należy więc spodziewać się, że warsztaty będą nadal organizowane w kolejnych latach, coroczni adepci będą mieć szansę na szlifowanie swojego warsztatu i integrację z przedstawicielami środowiska archiwalnego, zarówno akademickiego, jak i studenckiego.

Damian Sitkiewicz

\section{Ogólnopolski Zjazd Studentów Archiwistyki}

WW dniu 23 kwietnia 2009 r., podczas XI Ogólnopolskiego Zjazdu Studentów Archiwistyki w Katowicach, przedstawiciele studenckich archiwalnych kół naukowych zdecydowali o powierzeniu organizacji następnego spotkania Kołu Naukowemu Studentów Archiwistyki Uniwersytetu Wrocławskiego. Profesjonalne przygotowanie katowickiego zjazdu spowodowało, że przed organizatorami kolejnego dorocznego spotkania stanęło niełatwe zadanie, a zarazem duże wyzwanie przygotowania co najmniej porównywalnej pod względem naukowym i logistycznym konferencji, gromadzącej studentów archiwistyki z całego kraju.

Pierwsze kroki i działania związane z organizacją XII OZSA we Wrocławiu zostały podjęte w drugiej połowie 2009 r. KNSA UWr zwróciło się wówczas o objęcie honorowego patronatu nad konferencją do Marka Łapińskiego

4 Cyfrowy Radzyń, Wspólnota Radzyńska, nr 16 z 20 IV 2010, s. 8.

5 Zarządzajacy dokumentacją będą integrować się w Radzyniu, Wspólnota Radzyńska, nr 17 z 23 IV 2008, s. 7. 